\title{
VOLTAIRE E UM EPISÓDIO DA História De PORTUGal ${ }^{1}$
}

\section{José Oscar de Almeida Marques ${ }^{2}$}

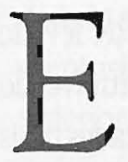

m seu Resumo do século de Luís XV ${ }^{3}$ Voltaire dedica duas passagens a acontecimentos ocorridos em Portugal: a devastação de Lisboa pelo terremoto

de 1755 e 0 atentado, três anos mais tarde, contra o rei D. José I e a subseqüente retaliação que eliminou o poder e a influência da alta nobreza e dos jesuítas nos assuntos do Reino. Com isso, Voltaire faz aflorar duas pontas de uma história, mas mantém submersa a linha contínua que as une e torna-as, como proponho no título, partes de um único episódio. Preenchendo as lacunas e corrigindo algumas imprecisões do relato de Voltaire, pretendo trazer à luz essa unidade. 0 que significa, principalmente, trazer à luz a atuação do todo-poderoso ministro Sebastião José de Carvalho e Melo, Conde de Oeiras e Marquês de Pombal. ${ }^{4}$

Que o próprio Voltaire não tenha explicitado essa conexão - ou, como é mais provável, que a desconhecesse - não constitui motivo de crítica. Acontecimentos na natureza ou na história não trazem consigo etiquetas que os classifiquem nem ganchos que os liguem entre si, e é só a narrativa do historiador, após um demorado processo de

1 Conferência do Workshop "Intelectuais e Poder: elementos para a análise do discurso político". Universidade Estadual de Londrina, 10 de setembro de 2004.

2 Professor do Departamento de Filosofia da Universidade Estadual de Campinas.

3 Voltrare. Précis du siècle de Louis XV. (1768). Edition Moland, vol. XV. pp. 143-435.

4 Sebastião José de Carvalho e Melo (1699-1782) recebeu sucessivamente do rei D. José I os títulos de Conde de Oeiras (1759) e Marquês de Pombal (1770), sendo mais conhecido por este último. Para evitar o anacronismo, vou referir-me a ele sempre pelo seu nome. Foi a mais notável e mais controversa figura de Portugal setecentista, e a avaliação dos aspectos benéficos e danosos de sua atuação desafia até hoje a análise dos cronistas e historiadores, separando-os em campos irreconciliáveis. Procurei, em minha pesquisa, apoiar-me em trabalhos que refletem essa diversidade. Camilo Castelo Branco (Castelo Branco, C. o perfil do Marquês de Pombal (1882). Lisboa: Folhas e Letras, 2003) constitui seu crítico mais implacável e vê sua atuação de forma uniformemente negativa. Mário Dominguez (Domingues, M. Marquês de Pombal: o bomem e sua obra (1955). Lisboa: Prefácio, 2002), escrevendo de uma perspectiva mais à esquerda, 0 avalia de forma equilibrada e destaca seus méritos sem poupá-lo de críticas. Por fim, a extensa análise de Teixeira Soares (SOAREs, T. 0 Marquês de Pombal: a lição do passado e a lição do presente. Rio de Janeiro: Alba, 1961) é, na maior parte favorável, e busca restituir-lhe um lugar de primeira grandeza no processo de modernização de Portugal. 
intelecção, que lhes pode conferir o sentido e a unidade que por si sós não possuem. Estamos hoje acostumados a falar da ligação entre o terremoto de 1755 e a consolidação do poder quase absoluto de Pombal, que lhe permitiu reformar a ferro e fogo a sociedade e as instituições portuguesas, e impor uma derrota implacável a seus inimigos instalados nas altas casas da nobreza e na Companhia de Jesus. ${ }^{5}$ Mas Voltaire, escrevendo poucos anos depois sobre fatos ocorridos no que certamente lhe parecia um obscuro recanto nas fronteiras da Europa civilizada, não tinha os meios e tampouco o interesse de analisá-los em maior profundidade. Brilhante historiador e, sobretudo, arguto observador dos governantes e de seus métodos, ${ }^{6}$ o que se pode talvez censurar a Voltaire é não ter levado mais a sério sinais que lhe teriam fornecido boas pistas sobre a tendência inelutável do século e o destino que aguardava a monarquia e a nobreza da França poucas décadas mais tarde.

\section{O Terremoto e o Filho do Terremoto}

A primeira passagem que Voltaire dedica a Portugal no Resumo ocorre logo no início do capítulo 31, no qual se aborda o período de turbulências marcado pela Guerra dos Sete Anos (1756-1763):

Os novos males da Europa parecem ter sido anunciados por tremores de terra que se fizeram sentir em muitas províncias, mas de forma mais terrível em Lisboa que em outras partes. Um terço da cidade desabou sobre seus habitantes; quase trinta mil homens pereceram [...] Esse flagelo deveria fazer os homens meditarem e perceberem que, de fato, não passam de vítimas da morte, que deviam ao menos consolar-se uns aos outros. Os portugueses acreditaram obter a clemência de Deus fazendo queimar judeus e outros homens no que denominavam um "auto-de-fé", ato que outras nações consideravam um ato de barbárie; mas exatamente a partir dessa época adotaram-se medidas em outras partes da Europa para ensangüentar esta terra que desmoronava sob nossos pés".

5 Essa ligação expressa-se claramente na conhecida passagem de Oliveira Martins: "O terramoto [de Lisboa] durou cinco anos (1755-1760) e subverteu as ruas e as casas, os templos, os monumentos, as instituições, os homens, e até as suas idéias. E sobre as ruínas e destroços da cidade maldita levantou-se a Jerusalém do utilitarismo burguês; sobre as migalhas de Síbare, a efêmera Salento do Marquês de Pombal..." Ounvira Martins, J. P. História de Portugal (1879). Lisboa: Imprensa Nacional - Casa da Moeda, 1988. p. 172.

6 Para um informativo estudo sobre Voltaire historiador e analista político, ver LoPES, M. A. Voltaire político: espelbos para príncipes de um novo tempo. São Paulo: Editora UNESP, 2004.

7 Précis, p. 335-6. Todas as passagens de Voltaire foram traduzidas por mim. 
Esta curta passagem funciona no texto de Voltaire apenas como um prólogo ao relato das catástrofes políticas do período em questão, que constituem propriamente 0 assunto do capítulo. Mas seria errôneo deduzir disso que a catástrofe geológica e humanitária de Lisboa (então a quarta maior cidade européia) tivesse deixado Voltaire indiferente. Ao contrário, ela o marcou muito, levando-o a compor febrilmente, nos dois meses seguintes, seu Poema sobre o desastre de Lisboa, no qual colocou em dúvida a existência de uma providência divina, por lhe parecer impossível conciliar tal providência com a morte de tantos inocentes. De fato, o acontecimento pode ter constituído um divisor de águas na produção de Voltaire, separando suas obras iniciais, mais positivas e confiantes, de seus escritos posteriores, marcados cada vez mais pelo ceticismo e o sarcasmo.

Nesse sentido, é significativo que o terremoto de Lisboa também figure em um importante episódio da obra mais famosa de Voltaire, o conto filosófico Cândido ou o otimismo, de 1759, no qual todo o sarcasmo e a ironia do autor se voltam contra as doutrinas otimistas de que tudo está bem, e de que vivemos "no melhor dos mundos possíveis". No conto, o terremoto surpreende Cândido e seus companheiros de viagem quando acabam de chegar a Lisboa:

Tão logo puseram o pé na cidade [...] sentem a terra tremer sob seus passos; o mar se ergue fervilhando sobre o porto e destrói os navios ancorados. Turbilhões de chamas e de cinzas cobrem as ruas e as praças públicas, as casas desmoronam, os tetos tombam sobre as fundações e estas se desfazem. Trinta mil habitantes de todos os sexos e idades são esmagados sob as ruínas. ${ }^{8}$

E no capítulo seguinte, antecipando o que diria nove anos mais tarde no Resumo, Voltaire refere-se à realização de execuções públicas como meio de aplacar a cólera divina:

Após o tremor de terra que destruíra três quartos de Lisboa, os sábios do país não haviam encontrado um modo mais eficaz de prevenir uma ruína total que o de dar ao povo um belo auto-de-fé. Fora decidido pela Universidade de Coimbra que 0 espetáculo de algumas pessoas queimadas a fogo lento, em grande cerimônia, era um segredo infalível para impedir a terra de tremer. [...] Conseqüentemente, foram apanhados um basco acusado de ter desposado sua comadre e dois portugueses que, ao comer um frango, haviam tirado fora o toicinho, e vieram buscar, após o jantar, o Dr. Pangloss e seu discípulo Cândido. [...] Cândido foi açoitado ritmicamente

8 Cândido, cap. V. In Voltare Romans et contes. Paris: Gallimard, 1972. p 148.

9 Cândido, cap. VI. Ibid. pp. 150-1. 
ao som de um canto, o basco e os dois homens que não quiseram comer toicinho foram queimados e Pangloss foi enforcado, embora isto não fosse o costume.?

Se a natureza ficcional do Cândido admite o fantasioso relato sobre esse auto-defé, é surpreendente que Voltaire o tenha incluído (incluindo-se a referência a judeus executados) no texto histórico do Resumo. Pois o que se viu em Lisboa nas semanas subsequientes ao desastre não foi nada disso, mas um esforço hercúleo para prover abrigo, assistência e alimento à população atingida e manter a ordem e o funcionamento da sociedade. Nesse momento de grandes desafios consolidou-se a carreira de um homem, 0 ministro Sebastião José de Carvalho e Melo, que assumiu com suficiente competência e discernimento as tarefas exigidas pela situação, ascendendo enormemente em prestígio aos olhos do atemorizado e inseguro monarca D. José I. Para ele, a destruição causada pelo terremoto significou uma dádiva da fortuna, a oportunidade ímpar que lhe abriu o caminho para as reformas de que, a seu juízo, Portugal carecia. Nas palavras de Oliveira Martins,

"0 terramoto era o fim de um mundo. Antes de criar, porém, o ministro precisava consagrar a destruição nas esferas onde a natureza não chega — na sociedade, nas instituições... 0 terramoto fez-se pois homem, e encarnou em Pombal, seu filho". ${ }^{10}$

Dedicado integralmente às providências práticas necessárias para enfrentar os problemas imediatos e - o que é mais importante - ao preparo dos planos para a reedificação da área urbana segundo um traçado moderno e funcional, Carvalho e Melo sentiu-se extremamente desgostoso com a atitude de alguns setores do clero que procuravam levar ao povo a idéia de que o terremoto fora um castigo divino pela impiedade dos governantes e que, ao invés de providências práticas, o que se necessitava era jejuns, procissões e penitência. Para o ministro, ao contrário, apesar de algumas medidas contemporizadoras com a religiosidade popular, ${ }^{11}$ era óbvio que terremoto tivera causas naturais, quanto às quais nada se podia fazer, e o reparo de seus efeitos exigia ações muito distintas da realização de procissões e autos-de-fé. Houve, é certo, um sem número de execuções para desencorajar roubos e pilhagens, mas manifestações de fanatismo religioso do tipo aludido por Voltaire não foram toleradas e muito menos promovidas. ${ }^{12}$

10 Oliveira Martins, História de Portugal.pp. 176-7.

11 Como a expulsão dos amancebados para fora da cidade de Lisboa e a dedicação da cidade a um novo santo padroeiro.

${ }^{12}$ Houve três autos-de-fé em Lisboa nos três anos subseqüentes a 1755, mas nenhum deles esteve ligado ao terremoto e neles não houve tampouco execuções. 


\section{Os Jesuítas e o Padre Malagrida}

Deixemos de lado, por ora, o terremoto, e passemos ao exame da segunda passagem do Resumo que Voltaire dedicada a acontecimentos passados em Portugal. Ela se situa no início do capítulo 38 e trata da tentativa de assassinato do rei D. José I e da expulsão dos jesuítas de Portugal e territórios.

Voltaire principia observando que uma ordem religiosa não deveria fazer parte da história, e que é uma lástima que homens destinados pelo sacerdócio ao silêncio e à oração rivalizassem em notoriedade, à época, com os príncipes, "seja por suas imensas riquezas, seja pelas agitações que promoveram desde sua fundação". ${ }^{13}$ É desnecessário lembrar aqui a notória hostilidade de Voltaire (e, em geral, do partido dos philosophes) contra os jesuítas, freqüentemente acompanhada da denúncia de uma fabulosa riqueza canalizada para a obtenção de poder e controle político das instituições. Para as teorias conspiratórias da época, também era clara a fonte dessas riquezas: a prata e o ouro do Novo Mundo, e a exploração direta dos recursos desses territórios por meio da mão de obra indígena que os jesuítas controlavam:

Os jesuítas eram, como se sabe, os verdadeiros soberanos do Paraguai, apesar de reconhecerem 0 rei da Espanha. A corte da Espanha havia cedido por um tratado ${ }^{14}$ alguns distritos desses territórios ao rei de Portugal José II, da casa de Bragança. Os jesuítas foram acusados de se opor a esse tratado e insuflar a revolta das populações que deveriam passar para o domínio português. Essa queixa, somada a muitas outras, fez com que os jesuítas fossem expulsos da corte de Lisboa. ${ }^{15}$

Apesar de equivocar-se quanto ao nome, ou número, correto do rei de Portugal, Voltaire está certo ao identificar os conflitos gerados entre os jesuítas e os políticos que pretendiam implementar o Tratado de Madri como a origem dos desenvolvimentos que levariam à derrota e expulsão da Companhia de Jesus de Portugal. Mas há alguns elos faltantes em sua apresentação que merecem ser preenchidos. Ou antes, deve-se atentar para a atuação de dois protagonistas que, à sua maneira, representam os pólos em confronto e cuja atuação cobre todo o período que estamos aqui discutindo - o "período do terremoto" em sentido amplo, que principiou no abalo sísmico que destruiu a capital

\footnotetext{
13 Précis p. 395.

${ }^{14} 0$ Tratado de Madri, assinado em 13 de janeiro de 1750, pelo qual Portugal entregava à Espanha a Colônia do Sacramento, à beira do Prata, em troca dos Sete Povos das Missões.

15 Précis p. 395.
} 
portuguesa, prolongou-se pelo terremoto institucional e político que afetou todo o reino, e encerrou-se de forma inglória na Praça do Rossio, em setembro de 1761. Jáfalamos de um desses protagonistas, o ministro Carvalho e Melo; cabe agora apresentar 0 outro, a figura não menos controversa do padre jesuíta Gabriel Malagrida.

Nascido na Itália, o padre Malagrida passou boa parte de sua vida no Brasil, onde chegou em 1721, aos 32 anos de idade, para devotar-se a uma intensa atividade missionária. Depois de alguns anos como pregador no Colégio dos Jesuítas do Pará, mudou-se para São Luís, onde começou a voltar suas pregações também para as ruas. Visionário e místico, devia ter considerável poder de oratória, e em breve já era visto pelo povo como um santo, ao qual se atribuíam vários milagres. Quando se transferiu para a Bahia, em 1736, sua fama era tão grande que multidões vieram acompanhá-lo e ouvi-lo em sua passagem pelas diversas cidades do trajeto. E até hoje o nome de Malagrida élembrado em versos e cantos nos rincões do Pará, do Maranhão e da Bahia.

Malagrida foi um empreendedor incansável que construiu conventos e seminários por toda parte, trabalhando muitas vezes ele próprio nas construções. Nesse ardor, seu gênio assemelhava-se ao do ministro Carvalho e Melo com quem em breve iria defrontarse. Em 1747, necessitando de recursos para a edificação de um novo convento no Paráe não conseguindo arrecadá-lo entre os colonos (que estavam descontentes com a proteção que os jesuítas davam aos índios, impedindo-os de serem escravizados), decidiu partir para a metrópole para solicitá-los ao então rei D. João V. Sua fama há muito já havia cruzado o oceano, e sua recepção em Lisboa foi triunfal. 0 rei, muito enfermo e ansiando por uma recuperação, entregou-se incondicionalmente a seus cuidados, e toda a corte, por modismo ou convicção, aderiu às severas práticas e exercícios espirituais que o santo monge lhes prescrevia. Seu renome era grande também entre o povo simples das ruas, que fazia séquitos à sua passagem. 0 rei morreu em seus braços e ele ainda assistiu, antes de seu retorno ao Brasil em 1751, à subida ao trono de D. José I e à nomeação de Carvalhoe Melo para a Secretaria de Estado do Reino.

Sua segunda visita a Portugal, da qual não mais retornaria, deu-se em condições bastante diferentes. Chamado para prestar assistência à rainha viúva em seus últimos momentos, como fizera com o velho rei, Malagrida encontrou, na Lisboa de 1754, um clima, se não de hostilidade, de marcante indiferença. Carvalho e Melo, que sempre tinha mantido boas relações com os jesuítas e devia em boa medida à Companhia sua nomeação, encontrava-se às voltas com a declarada rebeldia dos jesuítas das Missões do Paraguai que não desejavam abandonar as populações indígenas que tinham sob seu controle à sanha escravagista dos colonos portugueses. E, de fato, os grandes recursos 
prometidos por D. João V a Malagrida para as missões no norte do Brasil não se haviam materializado, por interferência do ministro Carvalho e Melo. 0 pior, porém, era que a aura do padre Malagrida parecia esgotada e as pessoas não se mostravam mais tão interessadas em suas prédicas e exortações. Ou, pelo menos, esse interesse estava adormecido, necessitando de algum acontecimento espetacular para ser reavivado.

Esse acontecimento foi proporcionado pelo terremoto de 1755. Malagrida rapidamente assomou a liderança de um grupo de pregadores que pretendiam associar a catástrofe à falta de devoção nos altos círculos do governo. A idéia de um castigo divino deveria parecer apropriada a Malagrida, em vista do contraste entre a situação presente e o entusiasmo religioso, genuíno ou aparente, que ele testemunhara em sua estadia anterior na corte. Seus inflamados sermões foram publicados em um panfleto intitulado Juizo da verdadeira causa do terramoto que padeceu a corte de Lisboa no $1^{\circ}$ de Novembro de 1755, no qual, além de insistir na tese da punição divina, condenava severamente a construção de abrigos e os trabalhos de reedificação da cidade:

Sabe, Lisboa, que os únicos destruidores de tantas casas e palácios, os assoladores de tantos templos e conventos, homicidas de tantos de seus habitantes, os incêndios devoradores de tantos tesouros não são cometas, não são estrelas, não são vapores ou exalações, não são fenômenos, não são contingências ou causas naturais, mas são, unicamente, os nossos intoleráveis pecados. ${ }^{16}$

Para Carvalho e Melo, entretanto, o que era intolerável não eram os pecados, mas exatamente esse tipo de propaganda, que prejudicava a concentração de esforços e recursos na tarefa de reerguer das ruínas a capital portuguesa. Malagrida, com sua eloquiência e seu recuperado prestígio, passou a constituir um adversário formidável, que era preciso enfrentar com cautela para não pôr tudo a perder. 0 ministro beneficiou-se, porém, de uma malfadada predição de Malagrida e seu círculo de que o terremoto se repetiria um ano após sua ocorrência. Transcorrido o dia marcado sem que nenhum terremoto se fizesse sentir, Carvalho e Melo pôde passar à ofensiva, e, acusando Malagrida e seus seguidores de aterrorizar o povo e tirar proveito de superstições, fez queimar o panfleto e expulsou os rebeldes de Lisboa, confinando-os em Setúbal, do outro lado da foz do Tejo.

${ }^{16}$ Citado em Domingues, Marquês de Pombal, p. 178. É importante ressaltar que essa atitude de Malagrida não está em consonância com os traços mais característicos de sua ordem. Os jesuítas sempre estiveram profundamente envolvidos na atividade acadêmica, na ciência e na investigação. Em 1750, dos 130 observatórios astronômicos existentes no mundo, 30 eram dirigidos por astrônomos jesuítas, e 35 crateras lunares foram nomeadas em honra de cientistas jesuítas. Os jesuítas mais intelectualizados, entretanto, mesmo conscientes dos desvarios de Malagrida, não poderiam deixar de valorizar um tal aliado em sua campanha política contra Carvalho e Melo. 


\section{O MASSACRE DOS TÁvORAS}

Após vencer este primeiro round, Carvalho e Melo sentiu-se preparado para atacar outros inimigos mais bem posicionados e não menos perigosos. Mais uma vez, a fortuna jogou em seu favor, na forma do atentado contra D. José. Passemos de novo a palavra a Voltaire:

Algum tempo depois a família Távora, e sobretudo o duque de Aveiro, tio da jovem condessa Ataíde de Atouguia, o velho marquês e a marquesa de Távora, pai e mãe da jovem condessa, por fim, o conde Ataíde seu esposo, e um dos irmãos dessa infortunada condessa, acreditando ter recebido do rei uma ofensa irreparável, resolveram vingar-se dele. A vingança está bem de acordo com a superstição. Aqueles que planejam um grande atentado buscam entre nós casuístas e confessores que os encorajem. A família que julgava ter sido ofendida dirigiu-se a três jesuítas, Malagrida, Alexandre e Mathos. Esses casuístas decidiram que matar o rei não constituiria nem mesmo um pecado venial. [...] (3 de setembro de 1758) Os conjurados, munidos de seus perdões para 0 outro mundo, esperaram 0 rei que retornava a Lisboa de uma pequena casa de campo, só, sem criados e à noite; dispararam contra sua carruagem e feriram perigosamente o monarca. Todos os cúmplices, exceto um criado, foram presos. Uns morreram na roda, outros foram decapitados. A jovem condessa Ataíde, cujo marido foi executado, foi, por ordem do rei, chorar em um convento todos os horríveis males dos quais era considerada a causa. Apenas os jesuítas que haviam aconselhado e autorizado o assassinato do rei por meio da confissão, meio tão perigoso quanto sagrado, escaparam então ao suplício. ${ }^{17}$

Esta passagem é notável em diversos aspectos. Em primeiro lugar, é surpreendente que um historiador cuidadoso como Voltaire se equivoque em um fato tão conhecido e identifique D. Mariana, condessa de Atouguia, como a amante secreta do rei, quando todos os que estão familiarizados com o episódio sabem que essa duvidosa honra coube a D. Maria Teresa, casada com D. Luiz Bernardo, filho do marquês e da marquesa de Távora, ela própria também chamada marquesa de Távora, mas com o adendo "a nova" para distingui-la de sua sogra, D. Leonor de Távora. Fica-se a imaginar qual pode ter sido a fonte de Voltaire para essa atribuição, pois dificilmente alguma pessoa provida de informações sobre os assuntos portugueses se enganaria dessa forma.

Em segundo lugar, a indiferença com que Voltaire relata as execuções chama a

${ }^{17}$ Précis pp. 395-6. 
atenção, partindo de um homem que tanto se sensibilizou pelo martírio de Calas. ${ }^{18} \mathrm{De}$ fato, Voltaire parece se indignar menos com a barbaridade do massacre de Belém do que com o fato de que Malagrida e os demais jesuítas tenham escapado dele. É verdade que também na França, tão ilustrada, atos de regicídio eram punidos com tortura e execução públicas, como nos casos de Ravaillac em 1610 e Damien em 1757. Estes, entretanto, eram pessoas de baixa extração, ao passo que os Távoras pertenciam à mais alta nobreza do reino, tendo sido vice-reis nas possessões portuguesas na Índia. 0 ataque não se limitou aos executados, mas as prisões e confiscos se realizaram às centenas, de tal modo que as mortes nos cárceres e os degredos efetivamente varreram o clã de Portugal, e os pouquíssimos remanescentes abandonaram o sobrenome, banido dos registros do reino. Como exemplo de deliberado genocídio antiaristocrático, o caso português só seria superado nos anais da história européia moderna pelas atrocidades da Revolução Francesa e, mais tarde, da Revolução Russa.

A título de contraste, pela sua pungente sensibilidade, a célebre página de Camilo Castelo Branco sobre a execução da marquesa de Távora merece ser citado por extenso:

A aurora do dia 13 de janeiro de 1759 alvorejava uma luz azulada do eclipse daquele dia, por entre castelos pardacentos de nuvens esfumaradas que, a espaços, saraivavam bátegas de aguaceiros glaciais. 0 cadafalso, construído durante a noite, estava úmido. As rodas e as aspas dos tormentos gotejavam sobre o pavimento de pinho. Às vezes, rajadas de vento do mar zuniam por entre as cruzes das aspas e sacudiam ligeiramente os postes. Uns homens, que bebiam aguardente e tiritavam, cobriam com encerados uma falua carregada de lenha e barricas de alcatrão, atracada ao cais defronte do tablado. Às 6 horas e 42 minutos ainda mal se entrevia a facha escura com umas cintilações de espadas nuas, que se avizinhava do cadafalso. Era um esquadrão de dragões. 0 patear cadente dos cavalos fazia um ruído cavo na terra empapada pela chuva. Atrás do esquadrão seguiam os ministros criminais, a cavalo, uns com as togas, outros de capa e volta, e o corregedor da corte, com grande majestade pavorosa. Depois - uma caixa negra que se movia vagarosamente entre dois padres. Era a cadeirinha da marquesa de Távora, D. Leonor. Alas de tropa ladeavam o préstito. À volta do tablado postaram-se os juízes do crime, aconchegando as capas das faces varejadas pelas cordas da chuva. Do lado da barra reboava 0 mugido das vagas que rolavam e vinham chorar espumas no parapeito do cais. Havia uma escada que subia para o patíbulo. A marquesa apeou da cadeirinha, dispensando o amparo dos padres. Ajoelhou no primeiro degrau da escada, e

${ }^{18}$ Jean Calas, negociante de Toulouse, acusado de ter matado o filho para impedi-lo de abjurar o protestantismo, morreu na roda em 1762. Foi reabilitado em 1765 após uma célebre intervenção de Voltaire em seu favor. 
confessou-se por espaço de 50 minutos. Entretanto martelava-se no cadafalso. Aperfeiçoavam-se as aspas, cravavam-se pregos necessários à segurança dos postes, aparafusavam-se as roscas das rodas. Recebida a absolvição, a padecente subiu, entre os dois padres, a escada, na sua natural atitude, altiva, direita, com os olhos fitos no espetáculo dos tormentos. Trajava de cetim escuro, fitas nas madeixas grisalhas, diamantes nas orelhas e num laço dos cabelos, envolta em uma capa alvadia roçagante. Assim tinha sido presa um mês antes. Nunca lhe tinham consentido que mudasse camisa nem o lenço do pescoço. Receberam-na três algozes no topo da escada e mandaram-na fazer um giro no cadafalso, para ser bem vista e reconhecida. Depois, mostraram-lhe um a um os instrumentos das execuções, e explicaram-lhe por miúdo como havia de morrer seu marido, seus filhos, e o marido de sua filha. Mostraram-lhe a maça de ferro que devia matar-lhe o marido a pancadas na arca do peito, as tesouras ou aspas em que se lhes haviam de quebrar os ossos das pernas e dos braços ao marido e aos filhos, e explicaram-lhe como era que as rodas operavam no garrote, cuja corda lhe mostravam, e o modo como ela repuxava e estrangulava ao desandar do arrocho. A marquesa então sucumbiu, chorou muito ansiada, e pediu que a matassem depressa. 0 algoz tirou-lhe a capa, e mandou-a sentar em um banco de pinho, no centro do cadafalso, sobre a capa que dobrou devagar, horrendamente devagar. Ela sentou-se. Tinha as mãos amarradas, e não podia compor o vestido que caíra mal. Ergueu-se, e com um movimento do pé concertou a orla da saia. 0 algoz vendou-a; e ao pôr-lhe a mão no lenço que cobria o pescoço, - não me descomponbas - disse ela, e inclinou a cabeça que lhe foi decepada pela nuca, de um só golpe. ${ }^{19}$

Por fim, não deixa de surpreender que Voltaire simplesmente reproduza a "história oficial" do atentado, tal como fabricada por Carvalho e Melo, sem nenhuma ressalva ou indicação de que sua veracidade pudesse ser posta em dúvida. E, contudo, mais uma vez, é improvável que as falhas processuais, a implausibilidade do motivo, a precariedade dos depoimentos e a condução tortuosa de toda a investigação pudessem ter escapado a observadores bem posicionados. 0 segredo sobre 0 atentado ao rei foi mantido por mais de três meses, enquanto as diligências corriam secretamente. Identificados os suspeitos coincidentemente ásperos adversários do ministro -, as prisões se efetuaram num relance, e o processo e as execuções se cumpriram em menos de três semanas, ao arrepio de todas as práticas jurídicas estabelecidas. Sabe-se que os detalhes dos suplícios e das execuções, incluindo-se a tortura psicológica a que foi submetida D. Leonor Távora sobre o cadafalso, foram especialmente determinados por Carvalho e Melo. E até hoje persiste o mistério

19 Castelo Branco, 0 perfal do Marquês de Pombal. pp. 23-4. Na última edição de sua História de Portugal (1886), OLveira MARTNS reproduziu integralmente esta passagem de Camilo em uma nota de rodapé (pp. 180-1). 
sobre o que realmente ocorreu naquela noite de 3 de setembro, em que D. José I retornava de seu encontro amoroso, não estando descartada a possibilidade de que tudo tenha sido uma conveniente encenação.

Com o massacre dos Távoras, Carvalho e Melo conquistou uma posição tal que nenhum homem do reino, nobre ou eclesiástico, poderia fazer-lhe frente. Oparvenu, ao qual o duque de Aveiro se referia depreciativamente como "o Sebastião José", chegara ao poder quase absoluto, e a pouca distinção de suas origens sociais foi corrigida ao receber de D. José no mesmo ano o título de Conde de Oeiras. Mas se a contestação frontal estava afastada, havia ainda a temer as conjuras secretas, e principalmente, a força da Companhia de Jesus. É para ela que Carvalho e Melo se volta no último ato do terremoto.

\section{A Expulsão dos Jesứtas e o Fim de Malagrida}

Já notamos a indignação de Voltaire pelo fato de que Malagrida e os jesuítas que supostamente haviam aconselhado o regicídio tivessem escapado ao suplício e permanecessem, em vez disso, confinados (em número de treze, e não apenas três) no Forte da Junqueira. As imprecações de Voltaire contra os jesuítas e contra a tibieza das cortes portuguesas que não conseguiam puni-los prosseguem pelos parágrafos seguintes:

Como Portugal ainda não havia recebido na época as luzes que esclareciam tantos Estados na Europa, achava-se mais submetido ao Papa que qualquer outro país. Não era permitido ao rei condenar à morte, por meio de seus tribunais, um monge regicida; para isso era preciso o consentimento de Roma. Os outros povos estavam no século dezoito, mas os portugueses pareciam viver no século doze. [...] Para a posteridade, será difícil crer que o rei de Portugal tivesse solicitado a Roma por mais de um ano a permissão de levar ao tribunal os jesuítas seus súditos, sem conseguir obtê-la. A corte de Lisboa e a de Roma estiveram por muito tempo em um conflito declarado, e chegava-se mesmo a aventar de que Portugal se livraria de um jugo que a Inglaterra, sua aliada e protetora, já havia posto por terra há tanto tempo; mas o ministro português tinha inimigos em demasia para ousar empreender o que Londres havia concretizado, e mostrava ao mesmo tempo uma grande firmeza e uma extrema condescendência. ${ }^{20}$

Voltaire, entretanto, não dá nenhuma indicação de que os soberanos da França, da Espanha e de outros Estados católicos da Europa estivessem em melhor situação que o

${ }^{20}$ Précis pp. 396-7. 
de Portugal em relação à atribuição de julgar e condenar seus clérigos sem a permissão de Roma; assim, a relegação isolada de Portugal ao "século doze" parece arbitrária e preconceituosa. 0 contraste oferecido é antes com a Inglaterra, um caso muito peculiar em que a monarquia se pusera no controle da Igreja institucional desde o século XVI.

De fato, a alegada subserviência de Portugal a Roma parece na verdade exagerada, visto que Voltaire logo a seguir reconhece que as relações entre o governo português e 0 papa eram abertamente conflituosas. Sua menção ao projeto longamente acalentado por Carvalho e Melo de criar uma igreja nacional sob controle do Estado, baseada no modelo inglês, indica claramente que os objetivos políticos visados pelo ministro português o colocavam, nesse aspecto, bem à frente do que podia ser cogitado em outros Estados católicos, cuja fidelidade a Roma estava mais bem assentada.

Que Voltaire atribua a Carvalho e Melo os atributos opostos de "uma grande firmeza e uma extrema condescendência" é sintomático de uma dificuldade geral para avaliar a estratégia do ministro na questão político-religiosa. Sua propalada "reforma", na medida em que fez algo desse tipo, limitou-se à estatização do Santo Ofício e da Inquisição, o que na prática significou submeter essas duas instituições a seu efetivo controle pessoal. Mas ele não se dispunha a tomar a iniciativa do rompimento com Roma, e, em vista da renovada proteção do papa Clemente XIII à Companhia de Jesus, preparou-se para uma guerra de atrito e de propaganda que lhe permitiria conseguir seus objetivos com menos riscos e a um custo político mais aceitável.

Levar a julgamento e executar os jesuítas implicados no regicídio ter-lhe-ia permitido representá-los, e a toda a Companhia, como os verdadeiros mentores do ato, de quem os Távoras (agora já convenientemente eliminados) não seriam mais que os simples instrumentos. Mas se isso não era no momento possível, Carvalho e Melo certamente dispunha de outras alternativas igualmente eficazes; assim, após uma competente incursão pelo terreno das modernas técnicas de propaganda, com um bombardeio de panfletos e publicações que denunciavam todas as mazelas e conspirações reais ou imaginárias às quais os jesuítas eram popularmente associados, conseguiu que o monarca declarasse a Ordem fora da lei, por crimes contra Deus e o Estado, e determinasse sua expulsão de Portugal e de todos os territórios da Coroa. 0 extenso decreto foi assinado, simbolicamente, em 3 de setembro de 1759, data do primeiro aniversário do frustrado atentado ao soberano. Vejamos como Voltaire comenta essa medida:

Os jesuítas mais culpados estavam presos em Lisboa; o rei os deixou lá e tomou a decisão de enviar a Roma todos os jesuítas de seus domínios. Estes foram declarados banidos para sempre do reino, mas não se ousava aplicar a pena de morte aos três jesuítas acusados e condenados pelo regicídio. ${ }^{21}$

${ }^{21}$ Précis p. 397. 
A expulsão dos jesuítas de Portugal e territórios foi um ato de inaudita brutalidade que destruiu o sistema educacional do reino e das colônias, pela impossibilidade de se encontrar pessoas qualificadas para ocupar seus postos. A tragédia humanitária também foi imensa. Capturados de um dia para o outro, tendo todos os seus bens seqüestrados, foram conduzidos a prisões abarrotadas, à espera do envio definitivo para Roma, em completa miséria, para que o papa, seu protetor, os abrigasse e alimentasse. A pior sina foi a dos jesuítas do Ultramar, muitos velhos e doentes, que não resistiram às provações da travessia. Apenas do Brasil chegaram em 1760 por volta de 250 padres que, da viagem extenuante, foram lançados diretamente aos cárceres tenebrosos, onde a mortandade era enorme. Importantes trabalhos por eles realizados sobre as tribos, a fauna e a flora nativas, dicionários e gramáticas de línguas indígenas, tudo se perdeu na sanha persecutória e na pilhagem em busca das míticas riquezas nunca encontradas. 0 mesmo se deu nos estabelecimentos jesuíticos em Goa, em Macau, em Malabar. No entanto, Voltaire não tem uma palavra a dizer sobre esse ataque à História e à Ciência; tudo isso parece ser para ele de pouca importância frente à leniência para com os supostos mentores do regicídio. Voltemos a estes:

A única alternativa do rei foi entregar pelo menos um deles, Malagrida, à Inquisição, como suspeito de ter feito algumas afirmações temerárias que cheiravam a heresia. Os dominicanos, que eram juízes do Santo Ofício e assistentes do grande inquisidor, jamais gostaram dos jesuítas, e serviram o rei melhor do que Roma o teria feito. Esses monges desenterraram um pequeno livro da vida heróica de Santa Ana, mãe de Maria, ditado ao reverendo padre Malagrida por Santa Ana ela própria. Ela lhe havia declarado que a imaculada concepção lhe cabia tanto quanto à sua filha, que havia falado e chorado dentro do ventre de sua mãe, e tinha feito chorar aos querubins. Todos os escritos de Malagrida eram tão sábios quanto esse; além disso, ele havia feito predições e milagres, sendo que o de experimentar aos setenta e cinco anos poluções na prisão não foi o menor deles. Tudo isso the foi imputado em seu processo, e foi por isso que o condenaram à fogueira, sem sequer interrogá-lo sobre 0 assassinato do rei, já que este era apenas um crime secular, e o resto um crime contra Deus. Assim, a enormidade do ridículo e do absurdo somou-se à enormidade do horror. 0 culpado só foi levado a julgamento como um profeta, e só foi queimado por ser louco, não por ter sido regicida. ${ }^{22}$

Tendo subjugado os nobres e se livrado definitivamente dos jesuítas, restava ao recém titulado Conde de Oeiras uma última conta a acertar: as afrontas e acusações que 
Malagrida lançara contra o ministro em seus sermões e escritos, e mesmo face a face, não haviam sido esquecidas. Carvalho e Melo podia contentar-se com exilar os jesuítas e deixar os mais perigosos apodrecerem ocultamente nas prisões em vez de executá-los em público, mas o caso do padre italiano assumira uma dimensão pessoal e exigia uma vingança à vista de todos. Daí a pérfida escolha de fazê-lo condenar pela própria Inquisição, que, como vimos, estava sob suas ordens. 0 pobre pregador, cuja mente provavelmente jamais esteve em perfeito estado, havia piorado muito na prisão, e tomava seus delírios e alucinações como revelações, que consignava por escrito. Os hábeis e obedientes inquisidores não tiveram dificuldade em reunir um material suficientemente comprometedor para fundamentar a acusação de heresia, e foi como herege que Malagrida foi levado ao patíbulo.

Voltaire tem razão, portanto, ao afirmar que o horror somou-se ao ridículo, mas o que parece lhe importar não era tanto que Malagrida tivesse sido executado, mas que tivesse sido executado pelas razões erradas. Afinal, sempre se tratava de um jesuíta a menos, e, assim como d'Alembert, Voltaire estava convencido de que o espírito monástico era o flagelo dos Estados, e que era preciso destruí-lo começando pelos jesuítas, seus mais fortes representantes. Como escreveu a Helvétius nesse mesmo ano de 1761, "destruídos os jesuítas, venceremos a infame" ${ }^{23}$

Assim, em 20 de setembro de 1761, a Praça do Rossio em Lisboa assistiu um grande auto-de-fé como há tempos não se via. A presença de Malagrida entre os condenados - o único a ser levado à fogueira, além da efígie do Cavaleiro de Oliveira - dava finalmente a Voltaire seu tão proclamado auto-de-fé relacionado ao terremoto de 1755 , só que, ao contrário de sua expectativa, no cadafalso estava o místico proponente da tese do castigo divino, enquanto o algoz era o defensor da explicação naturalista da catástrofe... A leitura da sentença tomou duas horas, e nela Malagrida, "que foi Religioso Sacerdote da Companhia denominada de Jesus" era declarado "Herege de Nossa Santa Fé Católica e como tal relaxado à justiça secular [para] que com baraço e pregão seja levado pelas ruas públicas desta cidade até a Praça do Rossio, e que nela morra por morte natural de garrote, e que, depois de morto, seja seu corpo queimado e reduzido a pó e cinza para que dele e de sua sepultura não haja memória alguma" ${ }^{24}$

Estrangulado, seu corpo queimado e suas cinzas atiradas ao rio, Malagrida foi, seis anos depois que a terra tremeu em Lisboa, a última vítima do terremoto. 0 confronto entre dois homens que representavam dois espíritos ou duas épocas que se recusavam a

\footnotetext{
23 Apud Castelo Branco, p. 137.

${ }^{24}$ Citado em Domingues, p. 243.
} 
coexistir e a se compreender chegara a seu ato final. Nas palavras de Mário Domingues, 0 futuro marquês de Pombal atingira o ponto culminante da sua grandeza no mesmo momento em que descia ao nível mais baixo da miséria humana. ${ }^{25}$

\section{Conclusão}

0 caráter de Carvalho e Melo, a adequação de seus planos e programas de reforma e o impacto histórico dos 26 anos em que governou Portugal com mão de ferro são matérias sobre as quais reina e provavelmente sempre reinará uma grande controvérsia. Adeptos da esquerda e da direita, liberais e conservadores, democratas e elitistas encontrarão cada qual pontos de acordo e desacordo em suas avaliações dos métodos e objetivos do ministro de D. José. Para além dos episódios dramáticos aqui comentados, dos golpes políticos e das intrigas de bastidores, uma apreciação conseqüente deveria mergulhar a fundo na análise de seus projetos econômicos, administrativos, militares e educacionais.

Tal tarefa excede, é claro, os limites deste trabalho, que se propôs meramente a seguir o roteiro estabelecido pelo relato de Voltaire e corrigir, dentro de minhas capacidades, as distorções desse relato. EVoltaire nada fala sobre os projetos administrativos eeconômicos do ministro Carvalho e Melo. 0 que é de lastimar, pois Carvalho e Melo, assim como Voltaire, havia passado vários anos na Inglaterra e aprendera, também como Voltaire, a admirar a eficiência com a qual a sociedade e a economia inglesas eram administradas. Naturalmente, ele desejou transplantar alguns desses moldes administrativos para seu próprio país e modernizar a sociedade portuguesa, enfrentando as reações e empecilhos próprios desse tipo de empreendimento. E esses são tópicos aos quais Voltaire político e historiador dedicava geralmente grande atenção, e considerava como as marcas para aquilatar as virtudes dos governantes.

Por que teria Voltaire tratado tão pouco da obra política de Carvalho e Melo? As passagens acima citadas esgotam tudo o que ele tem a dizer sobre Portugal setecentista, e, como pudemos notar, incorrem em vários erros e simplificações pouco característicos do trabalho de um historiador competente. Ressalte-se, em oposição, que Portugal da época áurea das navegações e dos descobrimentos havia recebido a devida atenção de Voltaire em seu importante Essai sur les moeurs et l'esprit des nations. Parece, então, que Voltaire considerava Portugal de sua época um país esgotado, estagnado num passado obscurantista, e incapaz de prover qualquer exemplo digno de chamar a atenção de observadores interessados nas tendências daépoca. Isso explicaria seu tratamento superficial

${ }^{25}$ Domingues, p. 244. 
dos assuntos políticos portugueses e sua aceitação preguiçosa das explicações oficialmente difundidas, particularmente com relação ao processo dos Távoras e dos jesuítas. Se se trata de um país incapaz de gerar uma verdadeira dinâmica histórica e civilizacional, então não há motivo para dedicar esforço para deslindar o sentido de seus movimentos internos, que serão, por definição, estéreis e desinteressantes. Daí a utilização puramente retórica ou instrumental dos acontecimentos enfocados: eles surgem como fábulas ou apólogos que servem para transmitir uma certa "moral"; no caso de Voltaire, para veicular sua agenda liberal e anticlerical. Que sentido háem buscar a veracidade das fábulas? Elas são inventadas e apropriadas segundo os interesses e as circunstâncias. Seria por isso que o estilo de algumas passagens do Resumo apresentadas acima aproxima-se tão desconfortavelmente do relato caracteristicamente irônico e irreverente do Cândido?

$\mathrm{E}$, no entanto, se esse tiver sido realmente o julgamento de Voltaire, ele terá se equivocado. Os anos em que Carvalho e Melo esteve à frente do Estado português foram anos que viram o surgimento de políticas destinadas a ter um enorme papel na Europa das próximas décadas, e que foram na época atentamente observadas pelos meios diplomáticos. Ao promover burocratas, membros da burguesia e do baixo clero a posições de comando, Carvalho e Melo foi capaz de solapar a estrutura semifeudal de poder em Portugal, e obter forte apoio das camadas inferiores em sua luta com a nobreza e 0 alto clero. 0 latente projeto de uma igreja nacional, subordinada ao Estado, e o confronto declarado com Roma revelam também uma intenção de independência não expressada à época em outros países católicos europeus. De fato, sob Carvalho e Melo, Portugal se tornou o primeiro país católico da Europa a remover a influência da Igreja no governo, e a expulsão dos jesuítas revelou-se uma medida pioneira, logo seguida pela França (1764) epela Espanha (1767). A própria execução dos Távoras não foi senão um prenúncio do sangrento expurgo da nobreza ocorrido na Revolução Francesa.

Voltaire apresentou o tremor de terra de Lisboade 1755 como prenúncio dos conflitose guerras que $\log 0$ se seguiriam. Mas talvez não pudesse prever que 0 terremoto políicoinstitucional de 1755-1761 seria igualmente o prenúncio de uma era de revoluções e transformaç̃óes sociaise políticas que alterariam parasempreafacedaEuropa queeleconhecera.

Recebido em outubro de 2004. 